\title{
Investigation of urban birds as source of $\beta$-lactamase-producing Gram-negative bacteria in Marseille city, France
}

\author{
Edgarthe Priscilla Ngaiganam ${ }^{1}$, Isabelle Pagnier ${ }^{1,2}$, Wafaa Chaalal ${ }^{1}$, Thongpan Leangapichart ${ }^{1}$, Selma Chabou ${ }^{1}$, \\ Jean-Marc Rolain ${ }^{1,2}$ and Seydina Mouhamadou Diene ${ }^{1,2^{*}}$
}

\begin{abstract}
Background: We investigate here the presence of multidrug-resistant bacteria isolated from stool samples of yellowlegged gulls and chickens $(n=136)$ in urban parks and beaches of Marseille, France. Bacterial isolation was performed on selective media, including MacConkey agar with ceftriaxone and LBJMR medium. Antibiotic resistance genes, including extended-spectrum $\beta$-lactamases (ESBL) (i.e. bla $a_{\mathrm{CTX}-\mathrm{M},}$, bla $a_{\mathrm{TEM}}$ and bla $\left.a_{\mathrm{SHV}}\right)$, carbapenemases (b/a $a_{\mathrm{KPC}}$, bla $a_{\mathrm{VIM}}$, bla $a_{\mathrm{NDM}}, b / a_{\mathrm{OXA}-23}, b / a_{\mathrm{OXA}-24}, b / a_{\mathrm{OXA}-48}$ and bla $a_{\mathrm{OXA}-58}$ ) and colistin resistance genes ( $m c r-1$ to $m c r-5$ ) were screened by realtime PCR and standard PCR and sequenced when found.

Results: Of the 136 stools samples collected, seven ESBL-producing Gram-negative bacteria (BGN) and 12 colistinresistant Enterobacteriaceae were isolated. Among them, five ESBL-producing Escherichia coli and eight colistinresistant Hafnia alvei strains were identified. Four bla $a_{T E M-1}$ genes were detected in yellow-legged gulls and chickens. Three CTX-M-15 genes were detected in yellow-legged gulls and pigeons, and one CTX-M-1 in a yellow-legged gull. No mcr-1 to mcr-5 gene were detected in colistin-resistant isolates. Genotyping of E. coli strains revealed four different sequence types already described in humans and animals and one new sequence type.
\end{abstract}

Conclusions: Urban birds, which are believed to have no contact with antibiotics appear as potential source of ESBL genes. Our findings highlight the important role of urban birds in the proliferation of multidrug-resistant bacteria and also the possible zoonotic transmission of such bacteria from wild birds to humans.

Keywords: Chickens, Extended-spectrum beta-lactamases (ESBL), Marseille, Pigeons, Urban birds, Yellow-legged gulls

\section{Background}

Extended-spectrum beta-lactamases (ESBLs) are mainly plasmid-encoded enzymes that confer resistance to beta-lactams, including broad spectrum cephalosporins. They can be transmitted between bacteria by horizontal gene transfer (HGT) via mobile genetic elements such as recombinant plasmids, transposons or integrons [1]. These ESBL enzymes mainly include class A $\beta$-lactamases, such as TEM, SHV and CTX-M type, that confer resistance to penicillin and cephalosporin classes. However, CTX-M $\beta$-lactamase enzymes are

\footnotetext{
${ }^{*}$ Correspondence: seydina.diene@univ-amu.fr

${ }^{1}$ IRD, APHM, MEPHI, IHU-Mediterranee Infection, Aix-Marseille Univ, 19-21

bd Jean Moulin, 13005 Marseille, France

Full list of author information is available at the end of the article
}

the most emerged and reported worldwide [1]. ESBLproducing Enterobacteriaceae cause infections in both humans and animals through contaminations of water and food [2]. Over the past decade, a high prevalence of antibiotic resistance genes has been reported and has stimulated the search for multidrug-resistant bacteria in poultry, pigeons $[3,4]$ and birds in different countries [5]. In recent years, several reports indicated the presence of ESBL-producing bacteria among different species of urban and wild birds with no apparent exposure to antimicrobial drugs [6]. As reported by Bonnedahl et al. [7], 9.4\% of yellow-legged gulls (Larus michahellis) carried CTX-M type ESBL-producing E. coli in the South of France. Recently, Stedt et al. [8] have reported high and alarming levels of CTX-M genes in species of gulls 
in Europe and indicated that the ability of these birds to reach several countries could contribute to the spread of ESBLs. Therefore, pigeons and gulls, considered as migratory birds, have been pointed out as potential reservoirs and vectors for multidrug-resistant bacteria [8-10], especially gulls that are free-living aquatic birds. More recently, Wang et al. [11] have reported the role of wild birds in the global transmission of ESBL, AmpC $\beta$-lactamase, carbapenemase, and colistin resistance genes in Enterobacteriaceae. Because of their frequent movement in landfills and wastewater and the ease with which they collect food from various places, they can contribute to fecal contamination of natural water reservoirs or the food they come in contact with $[5,12]$. Face to this phenomenon, we aim here to investigate and to characterize $\beta$-lactamase-producing bacteria and colistin-resistant bacteria isolated from urban birds in the city of Marseille, France.

\section{Methods \\ Sample collection}

Between July and September 2016, six parks located respectively in four different districts of Marseille city, and one beach located in the 16th district of Marseille, were investigated (Fig. 1 and Additional file 1). A total of 136 stool samples from 71 pigeons (Columba liviaf. urbana), 28 chickens (Gallus gallus domesticus), and 37 yellow-legged gulls (Larus michahellis), were collected (Fig. 1 and Additional file 1). About $10 \mathrm{~g}$ of feces per sample was collected from the ground using sterile forceps and transferred into sterile $1.5 \mathrm{~mL}$ Eppendorf tubes. The samples were then immediately placed

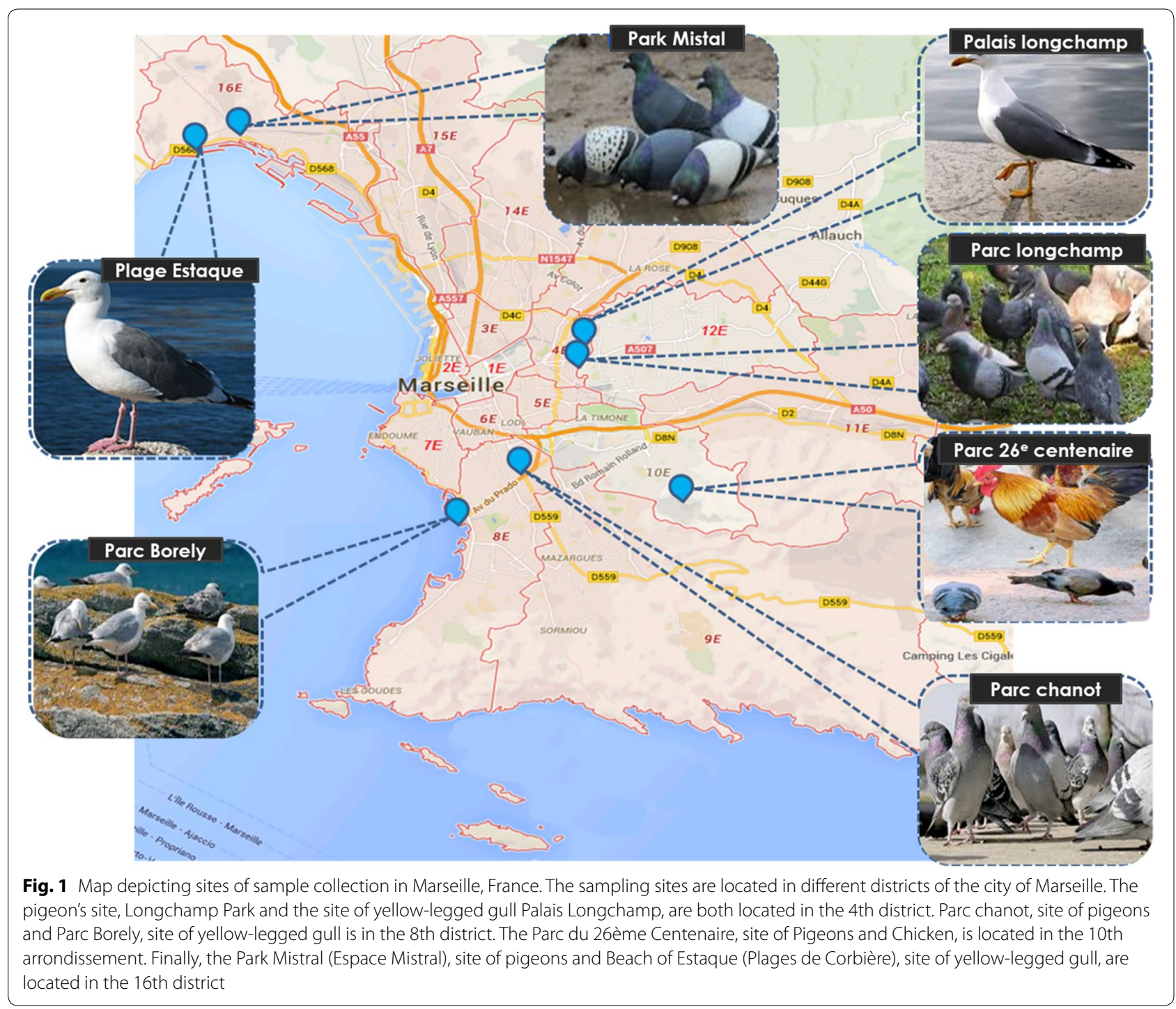


on ice during transport. Microbiological analyses were then carried the day after sampling.

\section{DNA extraction and ESBL detection}

Genomic DNA from 136 feces samples was prepared from an overnight incubation at $56{ }^{\circ} \mathrm{C}$ and extracted with the EZ1 DNeasy Blood Tissue kit (Qiagen GmbH, Hilden, Germany) using the protocol of the manufacturer. The presence of genes encoding for ESBLs (CTX-M, TEM and SHV, PER, GES, and VEB), carbapenemases (KPC, VM, NDM, OXA-23, OXA-24, OXA-48 and OXA-58) and $m c r-1$ to $m c r-5$ genes were investigated by real-time polymerase chain reaction (RT-PCR) with the specific primers as previously described [13-16]. Moreover, we designed here primers and probe for detection of All bla $a_{\text {TEM }}$ gene variants (ALLTEM_RT_F: 5'-TTCTGCTATGTGGTGCGG TA-3'; ALLTEM_RT_R: $3^{\prime}$-GTCCTCCGATCGTTG

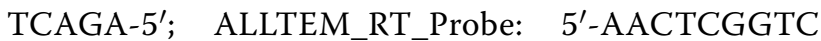
GCCGCATACACTATTCTCAGA-3').

\section{Isolation and identification of bacterial strains}

To isolate $\beta$-lactamase-producing bacteria and colistin resistant bacteria, $1 \mathrm{~g}$ of feces samples was mixed with $1 \mathrm{~mL}$ sterile water and $100 \mu \mathrm{L}$ were enriched in Tryptic Soy Broth $\left(\mathrm{BBL}^{\mathrm{TM}}\right.$ Trypticase $^{\mathrm{TM}}$ Soy Broth, Becton, Dickinson and Company Sparks, MD 21152, USA) and incubated overnight at $37^{\circ} \mathrm{C}$ for preliminary analysis. RTPCR targeting $\beta$-lactamase genes were used to screen all samples for positive ESBL genes. When a positive sample was suspected of isolates producing ESBL genes, bacteria were cultured on MacConkey agar medium with added ceftriaxone $(2 \mu \mathrm{g} / \mathrm{mL})$. On the other hand, in order to look for colistin resistant bacteria, all sample were directly cultured on the selective Lucie Bardet-Jean-Marc Rolain (LBJMR) medium [17] containing $4 \mu \mathrm{g} / \mathrm{mL}$ of colistin and $50 \mu \mathrm{g} / \mathrm{mL}$ of vancomycin. All cultures were then incubated at $37^{\circ} \mathrm{C}$ for $24 \mathrm{~h}$. From one to eight colonies of different morphologies were collected in each medium and reisolated on Trypticase Soy Agar (TSA, BioMerieux SA, France). Each of these colonies was subcultured 3 additional times to obtain a monoculture. Isolates were then identified by matrix assisted laser desorption/ionization, time of flight mass spectrometry (MALDI-TOF MS) and MALDI-Biotyper 3.0 software (Bruker Daltonics, Bremen, Germany) as described previously [18]. Bacteria are efficiently identified at the genus and species level when score values are ranging from 2.3 to 3.0 and at the secure genus identification and probable species identification when score values are ranged from 2.0 to 2.3 [18].

\section{Antimicrobial susceptibility testing}

Antibiotic susceptibility testing (AST) was performed using the agar disk diffusion method. Bacterial strains $(n=19)$ isolated from birds were suspended in a saline solution to a density of 0.5 McFarland. The surface of Mueller-Hinton agar plates (Merck, Darmstadt, Germany) was inoculated and the antibiotic disks were placed. After aerobic incubation at $37{ }^{\circ} \mathrm{C}$ for $18-22 \mathrm{~h}$, bacterial resistance was determined by measuring the inhibition zone according to the guidelines of CASSFM/EUCAST 2019 (v.1.0) (https://www. sfm-microbiologie.org/wp-content/uploads/2019/02/ CASFM2019_V1.0.pdf). The following antibiotics were tested ( $\mu \mathrm{g} /$ disk): amoxicillin (20), amoxicillin-clavulanic acid (20/10), cefepime (30), piperacillin-tazobactam (30/6), cefalotin (30), ceftriaxone (30), ertapenem (10), imipenem (10), fosfomycin (200), nitrofuran (100), trimethoprim-sulfamethoxazole (1.25/23.75), amikacin (30), ciprofloxacin (5), colistin (50), and gentamicin (10). For bacteria isolated on LBJMR medium, colistin MICs were determined by microdilution method using Mueller-Hinton (MH) liquid medium.

\section{Sequence analysis and MLST}

Aminoglycoside resistance genes (i.e. aad, ant, aph, $a a c(6)-I b, a a c(3)$, $\operatorname{arm} A$, and $a a c(6)-I b-c r)$ were investigated in Escherichia coli isolate (B32 strain) resistant to gentamicin and doxycycline. On overall, by qPCR and standard PCR we investigated genes encoding for extend-spectrum- $\beta$-lactamases $\left(b l a_{\mathrm{SHV}}, b l a_{\mathrm{VEB}}\right.$, $\left.b l a_{\mathrm{GES}}, b l a_{\mathrm{PER}}\right)$, carbapenemases (VIM, NDM, OXA-23, OXA-24, OXA-48, OXA-58), and mobile colistin resistance genes $(m c r-1$ to $m c r-5)$ using primers and probes previously reported [19].

All positive PCR products for genes encoding for ESBL that conferred resistance to 3rd generation cephalosporins were purified using the QIAquick PCR purification kit in concordance with the manufacturer's instructions (Qiagen, Hilden, Germany). Sequencing was performed using the BigDye Terminator Cycle Sequencing kit and an automated fluorescent DNA sequencer ABI 3730xl (Applied Biosystems, Foster City, CA, USA) in accordance with the manufacturer's instructions. The nucleotide sequences obtained were compared with those from the NCBI database by BlastN analysis. Multilocus sequence typing (MLST) was performed for five ESBL-producing $E$. coli isolates using genes from both the Warwick ( $a d k$, fumC, gyrB, $i c d, m d h$, purA, and recA) (http://mlst.warwick.ac.uk/ $\mathrm{mlst} / \mathrm{dbs} /$ Ecoli) and Pasteur Institute (icd, pabB, polB, putP, $\operatorname{trp} A$, and $\operatorname{trp} B$ ) (http://www.pasteur.fr/reche rche/genopole/PF8/mlst/) schemes. The ST not found 
in the database was submitted to the Pasteur MLST database to define the new profile.

\section{Results}

From the 136 stool samples from 71 pigeons (Columba livia f. urbana), 28 chickens (Gallus gallus domesticus), and 37 yellow-legged gulls (Larus michahellis), 15 samples were positive by the RT-PCR targeting ESBLencoding genes. The culture of these samples on the MacConkey with ceftriaxone medium reveals seven isolates from six samples (Table 1). On the selective LBJMR medium, the culture results to 12 isolates from 12 samples (Table 1). From the 19 isolated strains, bacterial identification by MALDI-TOF revealed, with a score ranging between 2.15 and 2.95, the presence of $E$. coli $(\mathrm{n}=5)$, Cronobacter sakazakii $(\mathrm{n}=1)$, Pseudomonas aeruginosa $(\mathrm{n}=1)$, Hafnia alvei $(\mathrm{n}=8)$, Proteus hauseri $(\mathrm{n}=1)$, Panteoa ananatis $(\mathrm{n}=1)$, Providencia alcalifaciens $(\mathrm{n}=1)$ and Serratia marcescens $(\mathrm{n}=1)$.
Only bacterial strains isolated on the MacConkey agar exhibited reduced susceptibility to 3rd generation cephalosporin (ceftriaxone) and only E. coli strains were resistant to cefepime (4th generation cephalosporin). Resistance also to trimethoprim-sulfamethoxazole, ciprofloxacin, doxycycline, and gentamicin was observed in some of these isolates (Table 1). However, all these strains from this MacConkey agar remained susceptible to carbapenems and colistin. For 3rd generation cephalosporin-resistant isolates, the standard PCR performed and sequencing revealed the presence of ESBL genes such as $b l a_{\text {CTX-M }}$ and/or $b l a_{\text {TEM }}$ with amino acid similarity ranging from 99.61 to $100 \%$ (Additional file 1). Four genes encoding two CTX-M variants were identified (Table 1). The $b l a_{\text {CTX-M-15 }}$ gene was found in three $E$. coli isolates from two yellow-legged gulls and one pigeon. Only one $E$. coli isolate from a yellow-legged gull harboured simultaneously $b l a_{\mathrm{CTX}-\mathrm{M}-1}$ and $b l a_{\text {TEM-1 }}$. Moreover, four $b l a_{\text {TEM-1 }} \beta$-lactamase genes were detected in two

Table 1 General features of all bacterial strains isolated from urban birds from the different investigated sites of Marseille city

\begin{tabular}{|c|c|c|c|c|c|c|c|c|}
\hline Strain name & Isolates & Sources & Sites & $\begin{array}{l}\text { Antibiotic resistance } \\
\text { phenotype }\end{array}$ & $\mathrm{MIC}_{\mathrm{CT}}(\mu \mathrm{g} / \mathrm{ml})$ & $b / a_{\text {СтX-M }}$ gene $^{a}$ & $b^{\prime} a_{\mathrm{TEM}}$ gene $^{\mathrm{a}}$ & MLST \\
\hline \multicolumn{9}{|c|}{ Bacterial strains isolated from the MacConkey agar } \\
\hline B11 & Escherichia coli & Yellow-legged gull & Site 1 & $\begin{array}{l}\text { AX, AMC, CRO, FEP, } \\
\text { STX, CIP }\end{array}$ & 0.25 & CTX-M-15 & - & ST10 \\
\hline B32 & Escherichia coli & Chicken & Site 2 & $\begin{array}{l}\text { AX, AMC, CRO, FEP, } \\
\text { STX, CN }\end{array}$ & 0.25 & - & TEM-1 & ST1652 \\
\hline B60 & Escherichia coli & Yellow-legged gull & Site 3 & AX, AMC, CRO, FEP, STX & 0.25 & CTX-M-15 & - & ST38 \\
\hline A61 & Escherichia coli & Pigeon & Site 2 & $A X, K F, C R O, F E P$ & 0.25 & CTX-M-15 & - & ST34 \\
\hline B62 & Escherichia coli & Yellow-legged gull & Site 3 & AX, AMC, CRO, FEP & 0.25 & CTX-M-1 & TEM-1 & ST857 \\
\hline B62 & Cronobacter sakazakii & Yellow-legged gull & Site 3 & $\mathrm{AX}, \mathrm{AMC}, \mathrm{CRO}, \mathrm{FF}$ & 0.25 & - & TEM-1 & - \\
\hline B34 & $\begin{array}{l}\text { Pseudomonas aerugi- } \\
\text { nosa }\end{array}$ & Chicken & Site 2 & $\mathrm{AX}, \mathrm{KF}, \mathrm{CRO}, \mathrm{F}, \mathrm{STX}$ & 0.25 & - & TEM-1 & - \\
\hline \multicolumn{9}{|c|}{ Bacterial strains isolated from the LBJMR agar } \\
\hline B42 & Hafnia alvei & Chicken & Site 2 & $A X, A M C, K F, C T$ & 8 & - & - & - \\
\hline B02 & Hafnia alvei & Yellow-legged gull & Site 1 & $A X, A M C, K F, C T$ & 4 & - & - & - \\
\hline B04 & Hafnia alvei & Yellow-legged gull & Site 1 & $\mathrm{KF}, \mathrm{CT}$ & 4 & - & - & - \\
\hline B11 & Hafnia alvei & Yellow-legged gull & Site 1 & $A X, A M C, K F, C T$ & 4 & - & - & - \\
\hline B21 & Hafnia alvei & Yellow-legged gull & Site 4 & $\mathrm{KF}, \mathrm{CT}$ & 4 & - & - & - \\
\hline B47 & Hafnia alvei & Chicken & Site 2 & $\mathrm{AX}, \mathrm{AMC}, \mathrm{KF}, \mathrm{CT}$ & 4 & - & - & - \\
\hline B59 & Hafnia alvei & Yellow-legged gull & Site 3 & $\mathrm{AX}, \mathrm{AMC}, \mathrm{KF}, \mathrm{FF}, \mathrm{F}, \mathrm{CT}$ & 4 & - & - & - \\
\hline A63 & Hafnia alvei & Pigeon & Site 2 & $\mathrm{AX}, \mathrm{AMC}, \mathrm{KF}, \mathrm{FF}, \mathrm{F}, \mathrm{CT}$ & 4 & - & - & - \\
\hline A61 & Panteoa ananatis & Pigeon & Site 2 & $\mathrm{AX}, \mathrm{AMC}, \mathrm{KF}, \mathrm{FF}, \mathrm{F}, \mathrm{CT}$ & $>256$ & - & - & - \\
\hline B05 & Proteus hauseri & Yellow-legged gull & Site 1 & $\mathrm{~F}, \mathrm{CT}$ & $>256$ & - & - & - \\
\hline B22 & Serratia marcescens & Yellow-legged gull & Site 4 & $\mathrm{~F}, \mathrm{CT}$ & $>256$ & - & - & - \\
\hline B36 & Providencia alcalifaciens & Chicken & Site 2 & $\mathrm{~F}, \mathrm{CT}$ & $>256$ & - & - & - \\
\hline
\end{tabular}

Site 1: Palais Longchamp; Site 2: Parc 26e Centenaire; Site 3: Plage Estaque; Site 4 : Parc Borely

$A X$ amoxicillin, $A M C$ amoxicillin-clavulanic acid, KF cefalotin, CRO ceftriaxone, FEP cefepime, ERT ertapenem, IMP imipenem, FF fosfomycin, F nitrofurantoin, SXT trimethoprim-sulfamethoxazole, CIP ciprofloxacin, $C T$ colistin, $C N$ gentamycin, $S T$ sequence type

a Obtained $\beta$-lactamase sequences were compared with reference protein sequences of bets hit sequences which were bla ${ }_{\mathrm{CTX}-\mathrm{M}-15}$ (JQ686199); $b / a_{\mathrm{CTX}-\mathrm{M}-1}$ (X92506); and $b a_{\mathrm{TEM}-1}$ (JQ735917) (cf. Additional file 2) 
E. coli, one C. sakazakii and one $P$. aeruginosa isolates from chicken and yellow-legged gulls (Table 1). Co-presence of ESBL-producing strains e.g. C. sakazakii and E. coli was observed in a yellow-legged gull sample. These latter were resistant to amoxicillin; amoxicillin-clavulanic acid, cefalotin, ceftriaxone and were positive for the $b l a_{\mathrm{TEM}-1}$ gene. One of the E. coli isolate (B32 strain) carrying $b l a_{\text {TEM-1 }}$ was resistant to gentamicin and doxycycline, but none of the seven aminoglycoside resistance genes investigated were detected in this isolate. Besides, as expected, all strains isolated on the LBJMR agar were resistant to colistin (MIC $\geq 4 \mu \mathrm{g} / \mathrm{mL}$ ) and included bacteria naturally resistant to colistin (Table 1 ). Resistance to $\beta$-lactams including amoxicillin, amoxicillin-acid clavulanic, and cephalothin was observed in most of $H$. alvei strains. Interestingly, for two $H$. alvei strains, an atypical resistance phenotype was observed, i.e. they were resistant to cephalothin but susceptible to amoxicillin (Table 1). All positive qPCR for targeted genes from samples were confirmed by standard PCR from isolated strains by culture of the corresponded sample. All these isolates were susceptible to carbapenems, amikacin, trimethoprim-sulfamethoxazole, ciprofloxacin, doxycycline, and gentamycin. Overall, qPCR and standard PCR searches for resistance genes encoding for $b l a_{\mathrm{SHV}}, b l a_{\mathrm{VEB}}$, $b l a_{\mathrm{GES}}, \quad b l a_{\mathrm{PER}}$, carbapenemases, and mobile colistin resistance genes were negative for all isolates.

Genotyping by MLST was performed for $E$. coli isolates and revealed five different sequence types (STs) including ST10, ST34, ST38, ST1652 and a new ST which has been defined as ST857. The E. coli ST10 and ST38 carried the $b l a_{\mathrm{CTX}-\mathrm{M}-15}$ gene and were from yellow-legged gulls, whereas the E. coli ST34 belonging to the ST10 complex was isolated from a pigeon and also harbored a $b l a_{\text {СТХ- }}$ M-15 gene. Finally, E. coli ST1652, isolated from a chicken, carried the $b l a_{\mathrm{TEM}-1}$ gene and the $E$. coli ST-new carried $b l a_{\mathrm{CTX}-\mathrm{M}-1}$ and was from yellow-legged gull.

\section{Discussion}

In this study, we report CTX-M and TEM $\beta$-lactamases in Gram-negative bacterial isolates from urban birds in Marseille. Unlike previous studies reporting a high prevalence of ESBL-producing bacteria in gulls [11, 20, 21] and chickens [3, 22, 23], we observe here, a low prevalence $(1.47 \%)$ of ESBL-producing bacteria in chickens. This is probably due to that they are domestic chickens that have never received food additives or growth factors and live only in non-livestock parks. Here, we isolated a $\beta$-lactamase-producing $P$. aeruginosa from a chicken which was susceptible to amoxicillin-clavulanic acid and harbored the $b l a_{\text {TEM-1 }}$ gene only. With respect to the literature, $P$. aeruginosa is considered as one of the leading causes of infections in livestock and companion animals and $P$. aeruginosa isolates producing ESBL genes, such as $b l a_{\mathrm{PER}-1}, b l a_{\mathrm{CTX}-\mathrm{M}}, b l a_{\mathrm{SHV}}$ and $b l a_{\mathrm{TEM}}$ were reported in camel meat with a high prevalence [24]. Moreover, ESBLproducing $P$. aeruginosa isolates have also been observed from clinical settings, poultry, cattle and vegetables [25].

Interestingly, there was a simultaneous presence of ESBL-producing C. sakazakii and E. coli in a yellowlegged gull. In 2015, a study conducted by Zurfluh et al. [26] reported the presence of $C$. sakazakii producing ESBL SHV-2 type in fresh vegetables imported to Switzerland from the Dominican Republic, India, Thailand and Vietnam. It should be noted that $C$. sakazakii is an opportunistic Gram-negative, pathogenic bacterium with no spore formation, sometimes associated with sporadic cases or brief outbreaks of sepsis, meningitis, encephalitis, necrotizing enterocolitis and bacteremia in adults and newborns preterm neonates [27]. In many cases, the reservoir of C. sakazakii is unknown, and there are increasing reports that powdered infant formula is the source of C. sakazakii infections [28]. Our isolate was resistant to cephalothin as described by $\mathrm{Xu}$ et al. [29] who reported Cronobacter spp. isolates resistant to cephalothin in ready-to-eat foods and the potential risk of consumer contamination.

Hafnia alvei, an anaerobic Gram-negative bacterium, was isolated from all species birds investigated here. They are often present in the environment and a part of the animal gut [30]. This bacterium is rarely isolated from humans but can sometimes be an opportunistic pathogen responsible for nosocomial infections [30, 31]. All $H$. alvei isolated from birds in this study were resistant to cephalothin and colistin, which is a natural resistance [31]. However, most of these isolates were also resistant to amoxicillin and amoxicillin-clavulanic acid but susceptible to ceftriaxone, which is similar to a study conducted by Angela et al. [32] on broad spectrum cephalosporin-resistant Enterobacteriaceae isolated from humans.

Except the ST857 new sequence type identified here, the ST10, ST38, ST34 and ST1652 ESBL-producing E. coli described here are widely reported in humans, animals and in the environment (waters and wild birds) [6, 33-35]. Therefore, our study is consistent with previous studies in which human and animal isolates shared mainly identical STs, suggesting a possible transmission. In France, very few studies have been conducted on urban birds and our study is the first to investigate antibiotic-resistant bacteria in parks and beaches. We observed that ESBL-producing Enterobacteriaceae were more frequently isolated from beach gulls than chickens and pigeons as reported by Stedt et al. [8]. They reported that the ESBL-producing bacteria were frequently detected in gulls (906 ESBLs from a 
collection of 3158 samples, 28.7\%) with significant variations in prevalence rates between countries. We also observed that the STs isolated in our study were completely different from the STs found in yellow-legged gull in the other sites of south of France [7]. Pets, such as dogs and cats, are potential sources of transmission of antibiotic-resistant bacteria due to their close contact with humans and the intensive use of antimicrobial agents in humans and in the domestic animals. It should be noted that parks are open to dogs that are suspected of being a source of resistance genes. Indeed, the spread of resistance can occur directly or indirectly, through feeding, water and animal waste disposal in farm fields. Therefore, our study supports the idea that the beaches can be considered as sources of antibioticresistant bacteria.

\section{Conclusion}

Urban birds can be vectors for the transmission of ESBLproducing bacteria between human and animals. It may be due to their close contact with human activities, in addition to the role of parks and beaches as a meeting place for domestic and human animals, urban birds and environmental waters. To the best of our knowledge, we report here, for the first time, the presence of antibioticresistant bacteria from birds, especially yellow-legged gulls and chickens, in Marseille's parks and beaches. Further works such as whole genome sequencing of such bacteria from birds of different regions would be interesting to investigate how such bacteria are circulating via urban birds.

\section{Supplementary information}

Supplementary information accompanies this paper at https://doi. org/10.1186/s13028-019-0486-9.

Additional file 1. Protein alignment of identified $\beta$-lactamase enzymes from bird samples. A) Sequence alignment of TEM-1 proteins compared with reference TEM-1 protein (JQ735917) retrieved from the ARG-ANNOT database. B) Sequence alignment of CTX-M proteins compared with reference proteins of CTX-M-15 (JQ686199) and CTX-M-1 (X92506). All sequenced bla $a_{\text {TEM-1 }}$ genes (814-bp) exhibited $99.61 \%$ aa similarity with the TEM-1 reference sequence. bla $a_{\mathrm{CTX}-\mathrm{M}-15}$ and bla $a_{\mathrm{CTX}-\mathrm{M}-1}$ genes (855-bp) exhibited $100 \%$ aa similarity with CTX-M-15 and CTX-M-1 respectively.

Additional file 2. Sampling details according to the investigated locations.

\section{Acknowledgements}

The authors thank CookieTrad for proofreading the manuscript.

\section{Authors' contributions}

J-MR and SMD conceived and designed the study. EPN collected the samples, analyzed and interpreted data. WC, TL, and SC contribute to the analyses. IP performed corrections and critical revisions. EPN, SMD, and J-MR drafted the manuscript and/or critical revisions. All authors read and approved the final manuscript.

\section{Funding}

This work was supported by the French Government under the «Investissements d'avenir» (reference: Mediterranee Infection 10-IAHU-03).

Availability of data and materials

Not applicable

Ethics approval and consent to participate

Not applicable.

\section{Consent for publication}

Not applicable.

\section{Competing interests}

The authors declare that they have no competing interests.

\section{Author details}

${ }^{1}$ IRD, APHM, MEPHI, IHU-Mediterranee Infection, Aix-Marseille Univ, 19-21 bd Jean Moulin, 13005 Marseille, France. ${ }^{2}$ IHU-Mediterranee Infection, Marseille, France.

Received: 19 February 2019 Accepted: 22 October 2019

Published online: 31 October 2019

\section{References}

1. Bevan ER, Jones AM, Hawkey PM. Global epidemiology of CTX-M $\beta$-lactamases: temporal and geographical shifts in genotype. J Antimicrob Chemother. 2017;72:2145-55.

2. Maciuca IE, et al. High prevalence of Escherichia coli-producing CTX-M-15 extended-spectrum beta-lactamases in poultry and human clinical isolates in Romania. Microb Drug Resist. 2015;21:651-62.

3. Chabou S, Leulmi H, Davoust B, Aouadi A, Rolain JM. Prevalence of extended-spectrum $\beta$-lactamase- and carbapenemase-encoding genes in poultry faeces from Algeria and Marseille, France. J Glob Antimicrob Resist. 2018;13:28-32.

4. Borges CA, et al. Wild birds and urban pigeons as reservoirs for diarrheagenic Escherichia coli with zoonotic potential. J Microbiol. 2017;55:344-8.

5. Báez J, et al. Molecular characterization and genetic diversity of ESBLproducing-Escherichia coli colonizing the migratory Franklin's Gulls (Leucophaeus pipixcan) in Antofagasta, north of Chile. Microb Drug Resist. 2015;21:111-6.

6. Poirel L, Potron A, De La Cuesta C, Cleary T, Nordmann P, Munoz-Price LS. Wild coastline birds as reservoirs of broad-spectrum- $\beta$-lactamaseproducing Enterobacteriaceae in Miami beach, Florida. Antimicrob Agents Chemother. 2012;56:2756-8.

7. Bonnedahl J, et al. Dissemination of Escherichia coli with CTX-M type ESBL between humans and yellow-legged gulls in the south of France. PLoS ONE. 2009;4:e5958

8. Stedt J, et al. Carriage of CTX-M type extended spectrum $\beta$-lactamases (ESBLs) in gulls across Europe. Acta Vet Scand. 2015;2:57-74.

9. Liakopoulos A, et al. Molecular characterization of extended-spectrumcephalosporin-resistant Enterobacteriaceae from wild Kelp Gulls in South America. Antimicrob Agents Chemother. 2016;60:6924-7.

10. Blanco-Peña K, Esperón F, Torres-Mejía AM, de la Torre A, de la Cruz E, Jiménez-Soto M. Antimicrobial resistance genes in pigeons from public parks in Costa Rica. Zoonoses Public Health. 2017;64:23-30.

11. Wang J, Ma Z-B, Zeng Z-L, Yang X-W, Huang Y, Liu J-H. The role of wildlife (wild birds) in the global transmission of antimicrobial resistance genes. Zool Res. 2017;38:55-80.

12. Migura-Garcia $L$, Ramos R, Cerdà-Cuéllar M. Antimicrobial resistance of Salmonella Serovars and Campylobacter spp. isolated from an opportunistic gull species, yellow-legged gull (Larus michahellis). J Wildl Dis. 2017;53:148-52.

13. Chabou S, Leangapichart T, Okdah L, Le Page S, Hadjadj L, Rolain J-M. Real-time quantitative PCR assay with Taqman((R)) probe for rapid detection of MCR-1 plasmid-mediated colistin resistance. New microbes new Infect. 2016:13:71-4. 
14. Kruger T, et al. Infections with nontyphoidal Salmonella species producing TEM-63 or a novel TEM enzyme, TEM-131, in South Africa. Antimicrob Agents Chemother. 2004:48:4263-70.

15. Roschanski N, Fischer J, Guerra B, Roesler U. Development of a multiplex real-time $P C R$ for the rapid detection of the predominant beta-lactamase genes CTX-M, SHV, TEM and CIT-type ampcs in Enterobacteriaceae. PLOS ONE. 2014;9:e100956.

16. Edelstein M, Pimkin M, Palagin I, Edelstein I, Stratchounski L. Prevalence and molecular epidemiology of CTX-M in Russian hospitals. Antimicrob Agents Chemother. 2003;47:3724-32.

17. Bardet L, Le Page S, Leangapichart T, Rolain JM. LBJMR medium: a new polyvalent culture medium for isolating and selecting vancomycin and colistin-resistant bacteria. BMC Microbiol. 2017;17:1-10.

18. Singhal N, Kumar M, Kanaujia PK, Virdi JS. MALDI-TOF mass spectrometry: an emerging technology for microbial identification and diagnosis. Front Microbiol. 2015;6:791.

19. Ly TDA, et al. Low prevalence of resistance genes in sheltered homeless population in Marseille, France, 2014-2018. Infect Drug Resist. 2019;12:1139-51.

20. Vergara A, et al. Prevalence of extended-spectrum- $\beta$-lactamase- and/ or carbapenemase-producing Escherichia coli isolated from yellowlegged gulls from Barcelona. Spain. Antimicrob Agents Chemother. 2017;61:e02071-16.

21. Dolejska M, Papagiannitsis CC. Plasmid-mediated resistance is going wild. Plasmid. 2018;99:99-111.

22. Dandachi I, Chabou S, Daoud Z, Rolain JM. Prevalence and emergence of extended-spectrum cephalosporin-, carbapenem- and colistin-resistant Gram negative bacteria of animal origin in the Mediterranean basin. Front Microbiol. 2018;9:2299.

23. Nahar A, et al. Prevalence and characteristics of extended-spectrum $\beta$-lactamase-producing Escherichia coli in domestic and imported chicken meats in Japan. J Vet Med Sci. 2018;80:510-7.

24. Elhariri M, Hamza D, Elhelw R, Dorgham SM. Extended-spectrum beta-lactamase-producing Pseudomonas aeruginosa in camel in Egypt: potential human hazard. Ann Clin Microbiol Antimicrob. 2017;16:21.

25. Odumosu BT, Ajetunmobi O, Dada-Adegbola H, Odutayo I. Antibiotic susceptibility pattern and analysis of plasmid profiles of Pseudomonas aeruginosa from human, animal and plant sources. Springerplus. 2016;5:1381.

26. Zurfluh K, Nüesch-Inderbinen M, Morach M, Berner AZ, Hächler H, Stephan R. Extended-spectrum- $\beta$-lactamase-producing Enterobacteriaceae isolated from vegetables imported from the Dominican Republic, India, Thailand, and Vietnam. Appl Environ Microbiol. 2015;81:3115-20.

27. Healy B, et al. Cronobacter (Enterobacter sakazakii): an opportunistic foodborne pathogen. Foodborne Pathog Dis. 2010;7:339-50.

28. Fei $\mathrm{P}$, et al. Prevalence, molecular characterization, and antibiotic susceptibility of Cronobacter sakazakii isolates from powdered infant formula collected from Chinese retail markets. Front Microbiol. 2017;8:2026.

29. Xu X, Li C, Wu Q, Zhang J, Huang J, Yang G. Prevalence, molecular characterization, and antibiotic susceptibility of Cronobacter spp. in Chinese ready-to-eat foods. Int J Food Microbiol. 2015:204:17-23.

30. Stanic M, Meusburger E, Hartmann G, Lhotta K. Hafnia alvei urosepsis in a kidney transplant patient. Case rep Transplant. 2015;2015:1-3.

31. Jayol A, Saly M, Nordmann P, Ménard A, Poirel L, Dubois V. Hafnia, an enterobacterial genus naturally resistant to colistin revealed by three susceptibility testing methods. J Antimicrob Chemother. 2017;72:2507-11.

32. van Hoek AHAM, Schouls L, van Santen MG, Florijn A, de Greeff SC, van Duijkeren E. Molecular characteristics of extended-spectrum cephalosporin-resistant Enterobacteriaceae from humans in the community. PLoS ONE. 2015;10:e0129085

33. Guo Y, et al. Frequency, antimicrobial resistance and genetic diversity of Klebsiella pneumoniae in food samples. PLOS ONE. 2016;11:e0153561.

34. Wong MHY, Yan M, Chan EWC, Liu LZ, Kan B, Chen S. Expansion of Salmonella enterica serovar typhimurium ST34 clone carrying multiple resistance determinants in China. Antimicrob Agents Chemother. 2013:57:4599-601.

35. Al Bayssari C, Olaitan AO, Dabboussi F, Hamze M, Rolain JM. Emergence of OXA-48-producing Escherichia coli clone ST38 in fowl. Antimicrob Agents Chemother. 2015;59:745-6.

\section{Publisher's Note}

Springer Nature remains neutral with regard to jurisdictional claims in published maps and institutional affiliations.
Ready to submit your research? Choose BMC and benefit from:

- fast, convenient online submission

- thorough peer review by experienced researchers in your field

- rapid publication on acceptance

- support for research data, including large and complex data types

- gold Open Access which fosters wider collaboration and increased citations

- maximum visibility for your research: over $100 \mathrm{M}$ website views per year

At BMC, research is always in progress.

Learn more biomedcentral.com/submissions 